\title{
Social Identity, Ethnicity and Internal Mobility in Indonesia
}

\author{
A. C. Tridakusumah, D. Supyandi, Y. Sukayat \\ Department of Socio-economics of Agriculture \\ Faculty of Agriculture, Universitas Padjadjaran \\ Bandung, INDONESIA \\ aktrikusuma@gmail.com
}

\begin{abstract}
Indonesia is a multiethnic country with more than 1000 ethnics and sub-ethnics. This ethnicity phenomenon played an important part on internal population mobility. Moreover, transmigration, a type of Indonesian internal mobility, is believed as a cultural project and interpreted as "Javanization" processes carried out by migrants from Central and East Java to the other islands in Indonesia. This paper aims to qualitatively describe social identity and ethnicity phenomena and their relation to internal mobility in Indonesia. In general, this study showed that Indonesian migration pattern is stable with increasing trend. Regional autonomy is a reason for this phenomenon, which opened big opportunity for jobs and investments. However, rural urban gap is still a major problem. Therefore, shifting growth centers to rural areas to foster rural industrialization and "agropolitan" are needed. Similarly, as a national development program, transmigration should develop better social life to pursue national unity and ready to anticipate social identity and ethnicity potential problems in the society. Finally, Expectation to have a better life in a new place and high social bond among Javanese, for sure, have changed social space identity in transmigration location to be a new social space which is more heterogeneous.
\end{abstract}

Keywords — social identity; ethnicity; internal mobility

\section{INTRODUCTION}

Since the colonial period, Indonesian national development cannot be separated from internal population mobility. An increase in development program has resulted in an increase in population mobility leading to an increase in development process [1]. Moreover, Zelinsky stated that there is a strong relationship between technology change and population mobility, internally and externally [2].

Technology change in Indonesian national development can be reflected from the growth of industrial sectors, which needed a lot of workers. About $89 \%$ of Indonesian industrial companies lie in Java Island, the other 9\% in Sumatera and 2\% in Sulawesi [3]. Based on this data, the Island of Java is a migrant destination. About $60 \%$ of Indonesian population and unemployment living in Java, and the wave of migrant to Java has been increasing for years.

As an archipelago country, Indonesia is a multiethnic country, with more than 1000 ethnics and sub ethnics [4], and Javanese is a dominant ethnic. According to Indonesian Population Census in 2000, Javanese covered $41.71 \%$ of Indonesian total population. Due to a long standing population inequality between Java Island and other islands in Indonesia, as well as problem of land ownership, the President Sukarno and Suharto administrations continued the Dutch colonial policy of population resettlement [5]. The policy was intended to spread population, consisting mostly of ethnic Javanese, more evenly over the region and to integrate the country's entire population through promulgating a homogenizing national culture. This process of integration was part of the Suharto government's "New Order" agenda for rural development.

Internal population mobility, such as internal migration, circulation and commutation has strong relationship with ethnicity phenomenon. Transmigration, as a type of internal migration, is a cultural project and is interpreted as "Javanization" processes, carried out by migrants from Central and East Java to the other islands (transmigration destinations) in Indonesia [6]. This paper aims to describe the social identities of internal mobility in Indonesia from the social space and ethnicity perspective.

\section{TRANSMIGRATION AND ETHNICITY IN INDONESIA}

Migration is a form of geographic, spatial, or territorial population movement among geographic units involving places of living change, which is from the origin to the destination. There are two types of migration, namely internal and international migrations. Internal migration is happened among geographic units in a country. A man doing migration is stated as inmigration based on destination place or stated as outmigration based on his origin place.

Though relatively understudied, as in [7] the transmigration program is globally recognized as one of the largest resettlement schemes ever implemented. There are other examples of large government-sponsored resettlement programs that were implemented with various goals, including population redistribution and agricultural development similar to transmigration.

Before discussing further about the transmigration, it helps us look at the background of lifetime migration in Indonesia based on the Central Bureau of Statistics data in Figure 1. In and out migration was important part of equitable development in Indonesia, and any mobility both outgoing and incoming population is the effect of various national development programs.

Along with population increase and technology progress through the growth of industries in several big cities, the in-migration and out migration have increased as well. Economic and political conditions and 
transportation access are push factors for Indonesian population to doing a migration.

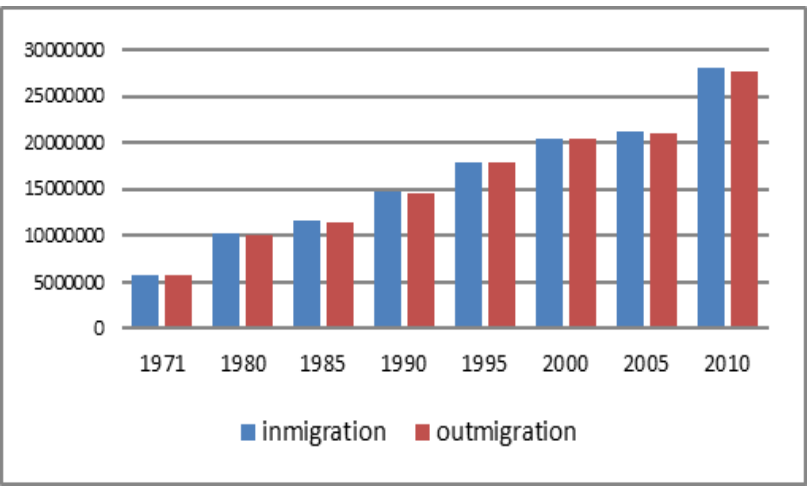

Fig. 1. Figure 1. Lifetime Migration 1971-2010

a. Source: BPS, 2010

One of the internal migrations having important role in out-migration and in-migration is transmigration. Trasmigration is a type of spatial mobility or horizontal population migration, driven by Indonesian government, and distinctively Indonesian, and has been be a program implementing for years. No other country implemented this transmigration program [8]. According to reference [9], transmigration is Indonesian government policy to move population from densely Java Island to other rarely islands, outside of Java.

According to Figure 1, Lampung Province is a largest destination province for transmigration of Java population, namely one milion people in 1971, and 1,7 million people in 1980. In 1990 the number has decreased, because some of the transmigrants moving to Lampung returned to the Java Island. Even though, the transmigrants have leaved their origin place for years, culturally, transmigrants from Central and East Java have prevented and practiced Javanese values and norms, such as language and performing arts in their new home.

Javanese is a largest ethnic in Province of Lampung. According to Population Census 2000, it contributed $61.89 \%$ of Lampung population. As seen in Figure. 2 this composition was determined by number of in-migrations to Province of Lampung, whether by transmigration program or through other mechanisms. Similarly in other provinces in Indonesia, Javanese are always exist and stayed permanently. Only in Provinces of Nusa Tenggara Barat and Nusa Tenggara Timur, the number of Javanese in these both provinces contributed less than $2 \%$.

Javanese and Sundanese are two biggest ethnics in Indonesia. However, the difference between the two is very significant. Indonesian population census 2000 stated that the number of Javanese is $41.71 \%$ and Sundanese is $17.46 \%$ of Indonesian population. As these two ethnics are joined, then they covered $59.17 \%$ or more than a half of Indonesian population.

Transmigration as one of internal mobility type, divided into two types, the general transmigration and spontaneous transmigration, as in [10] general transmigration (transmigrasi umum), or sponsored transmigration, is the name given to the program where the government provides transportation to the settlement site, as well as infrastructure, a house, and a living allowance intended to support the people until the first harvest. This form of transmigration has been progressively replaced with partially assisted spontaneous transmigration in locations such as Sumatra, where a significant number of people from Java are willing to move with their own expense. In Irian Jaya, however, fully sponsored general transmigration has persisted.

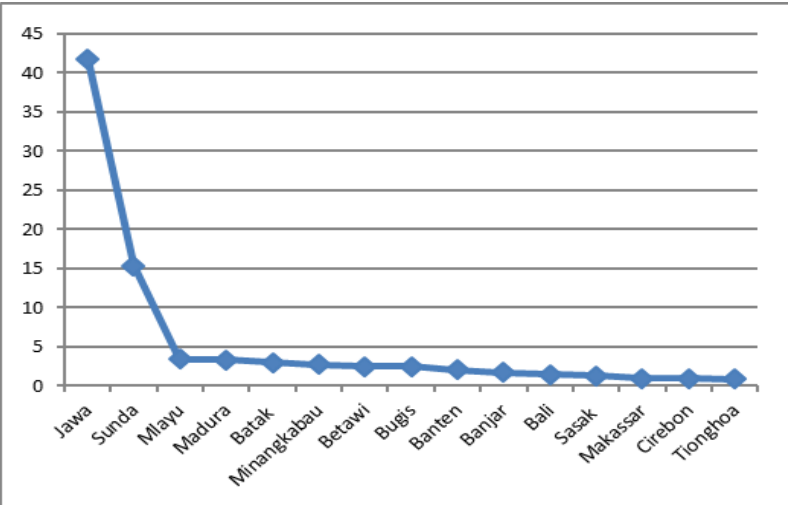

Figure 2. The percentage of the dominant ethnic group of Indonesian citizens based on Census 2000

b. Source: BPS (2000)

Both types of above transmigration will not be discussed in depth. This article emphasizes the discussion on the general form of transmigration, which is reviewed in terms of ethnicity and Indonesian nationalism that raises a new identity in a space where to place migrants in the destination area.

\section{DISCUSSION}

Literature comparative approach is used in this article in order to describe internal mobility phenomenon, which is transmigration, by using social space and ethnic identity concepts. This approach is used based on population census 2000 and 2010, and transmigration settlement data 2013 from the Ministry of Workforce and Transmigration (Kemenakertrans), which is now become the Ministry of Rural Area and Transmigration.

According to transmigrant settlement data form Kemenakertrans (2013), domination of Javanese ethnic in transmigration location in South Sulawesi in 2012 and 2013 has covered three villages, among others are transmigrant location Mahalona SP.4 at Towuti District, Luwu Timur Regency, transmigrant location Rante Karua SP.2 at Rinding Allo District, Toraja Utara Regency, and transmigrant location Bekkae SP.1 at Gilireng District, Wajo Regency, showed that of 400 transmigrant head of family, $31.0 \%$ are Javanese ethnic, $66.5 \%$ local population and Sundanese are $2.5 \%$. This previous case shows that transmigrants identity dominated by Javanese, not only in South Sulawesi, but also in other transmigration destination in Indonesia.

Several researches about the internal mobility or in this case transmigration program in Indonesia as in [11] have focused on specific aspects of the transmigration policy, the economic conditions of the settlers and the program's environmental impact (amongst others Hardjono 1977, Guiness 1977, Kebschull 1984, Fasbender and Erbe 1990, Fearnside 1997). In addition, research relating to the sociological and anthropological 
perspectives on the transmigration program have started to be conducted in the early 1990 s, such as the study of social spaces, adaptation, social integration, cultural acculturation, and so forth.

Transmigration population identity is in a social space, which according to Levfebre divided into three spaces, namely spatial practice, representation of space and representational space [12]. The existence of transmigrants play an important part in social, cultural, and economic developments, not only for transmigration actors, but also spacially, rooted in all people activities (spatial practices), and become a part of local people life, who formerly live in transmigration location (representational spaces). Role of government is important as representation of space through policies in the forms of regulations, laws and transmigration settlement studies. This is in line with Martanto opinion [13] that spatial practice is activities and interactions that define space, representation of space is space that has been conceptualized with goal to direct people actions. In the other hand, representational spaces are space where population and space users live.

Javanese as the biggest population ethnic in Indonesia, carried out their ethnic identity to transmigration destinations. Bourdieu stated that ethnic identity is a result and social construction developed between subject and object. Moreover, power of ethnic identity is power embodied on ethnic and become a mean of actors to organize and mobilize mass in living arena, such as social, economy and politic [14].

This state can be categorized as diaspora. Diaspora of Javanese at transmigration location indirectly forming their identity as Javanese. This situation according to reference [6] is called "diasporic project" or "Javanization" process, or can be defined as "homogenizing force aimed at securing national unity through the resettlement of Javanese transmigrants in remote areas, intensifying the presence of a Javanese centre in the country's margins."

The ethnicity paradigm, as in [15] such as the 'race' paradigm which is often merged into, has tended to focus on processes within the nation state rather than at transnational level. One of the reasons of the use of the concept of diaspora in the concept of internal mobility is being able to explain the paradigm of ethnicity and race more broadly and not just talking the distribution of population alone.

The remaining diasporas can be understood as arising from a mixture of underlying causes (such as poverty, insecure land tenure and overpopulation), which are combined with a variety of more immediate precipitating factors that serve to accelerate the basic movement or give to a particular character and direction [16]. For example, transmigration was essentially due to the density of population (overpopulation) in Java, but there are also some cases due to agricultural land in the area of origin is used for development purposes, such as the transmigration program for citizens due to the construction of dams in Jatigede in West Java and Kedungombo in East Java. The welfare of the Indonesian population, in accordance with population distribution and agricultural land cause diasporas in the destination areas. The situation also shows failing agricultural pursuits were given a renewed lease of life; family and kin were supported in their old age and in poverty, and sometimes more dramatic and far-reaching changes were initiated [16].

Transmigration is also directed to support national development and improving the welfare of the Indonesian people in general, so that development agencies such as government, NGO should: (a) secure the rights of migrants, (b) cut the cost of money transfers, (c) encourage migrants to invest in community initiatives in their home countries and (d) engage with pro-poor drivers of change at home [17]. Provision of living allowance for one year at the transmigration destination locations, facilities to support agricultural production, educational facilities and the access road to be part of the process of the placement of migrants into the goal area, so that at least resident migrants newly placed to adapt both socially and economically. However in reality, according to the case in South Sulawesi transmigration placement of the migrants get living allowance for one year, but the facilities and infrastructure such as houses, drainage and one hectare of land allocation is not fully adequate.

Diaspora approach that had been talked about ethnic in transactional setting is an interesting development in the internal cultural identity in a country. With ethnic and cultural diversity, Indonesia of course, can be approached with the concept of diasporas, so that the internal migration that occurred under Indonesia's transmigration program can explain better the identity of a place transmigration settlement seen from ethnicity and socioeconomic changes and culture due to the arrival of migrants to a destination place.

Ethnic identity of migrants who came from the island of cannot be denied coloring Indonesian national identity. The transmigration program other than as a way to equalize the population and development is also a good tool for the spread of Javanese culture are brought to the transmigration both economic and social, although currently there is resistance to the transmigration program, but as the dominant ethnic, Javanese culture remains a common identity in Indonesia.

National identity continues to be understood and experienced in ways that sometimes make it a barrier for newcomers who do not share the ethnicity and religious background of the native-born. National identity has always been socially constructed; it revolves around history, symbols, heroes and the stories that a community tells about itself. This sense of attachment to a place and a history should not be rubbed out, but it should be made as open as possible to new citizens [18].

Openness to newcomers or migrants can actually increase the integration of the nation if properly managed. Conflict and rejection that occurs become materials to establish the identity of the nation of Indonesia as a multicultural nation tht has its own identity, as compared with other countries both in the region in particular and Asia in general.

Population mobility from Java Island to outside of Java through transmigration program has brought about a change of social space in transmigration destination. The previous spatial practice, formerly filled by local people has been change into heterogeneous 
social space due to the arrival of trans migrants which are majority Javanese. These situations are conducting through government (local and national) roles in delivering socializations, studies, physical space management, which led to the impact on overall social space and everyday life, socially, culturally and economically. These social space changes are followed by the strengthening of Javanese ethnic identity, when it is seen from percentage of Javanese population as the largest participants of transmigration program.

\section{CONCLUSION}

As diaspora, transmigration program is an unfinished and unstable process. Transmigration could be a "Java-nization" representation, which is conducted by the government, where Javanese culture practices are implemented in everyday life in a social space. On the other hand, economic factors dominate the reasons of migrants to move to the other promising places for having a better life, in addition to the idea that national development must be in line with population distribution in Indonesia. Expectation to have a better life in a new place and high social bond among Javanese, for sure, have changed social space identity in transmigration location to be a new social space which is more heterogenous.

\section{ACKNOWLEDGMENT}

Fund: Department of Socio-economics of Agriculture Universitas Padjadjaran 2015, annual general funded faculty research project.

\section{REFERENCES}

[1] Abustam, M.I, Gerak penduduk pada komunitas padi sawah, studi kasus di tiga daerah pedesaan Sulawesi Selatan, IPB, Bogor, 1987.

[2] Liang Z, "The Sociology of migration. $21^{\text {st }}$ century sociology a reference handbook.", Sage Publication California US, pp 485495. 2006.
[3] Safrida, Sinaga BM, Siregar M, dan Harianto, "Dampak kebijakan migrasi internal terhadap perilaku pasar kerja di Indonesia”. Forum Pascasarjana, IPB, Bogor, 2008.

[4] Suryadinata L, Arifin EN, dan Ananta A, "Penduduk Indonesia, etnis dan agama dalam perubahan politik", LP3ES, Jakarta, 2003

[5] Hoey B, "Nationalism in Indonesia : building imagined and intentional communities through transmigration", Ethnology Vol. 42 no.2, pp 109-126, Spring 2003.

[6] Elmhirst R, "A Javanese Diaspora? Gender and identity politics in Indonesia's transmigration resettlement program", Women's Studies International Forum Vol. 23, No. 4, pp. 487-500, 2000.

[7] Bazzi. S. "Skill transferability, migration, and development: evidence from population resettlement in Indonesia", the Barcelona Summer Forum on Migration, the 7th Migration and Development Conference, Italy, December 2014.

[8] Suwartapradja, O. S, "Transmigrasi lokal: potensi dan tantangan", Jurnal Kependudukan. Vol 4 no 2, Maret 2002.

[9] Petersen W. dan Renee Petersen, "Dictionary of demography: terms, concepts, and institutions", Greenwood Press, New York US, 1986.

[10] Fearnside P, "Transmigration in Indonesia: lessons from its environmental and social impacts", Environmental Management Vol. 21, No. 4, pp. 553-570, 1997.

[11] Hoppe.M, Faust.A, "Transmigration and integration in Indonesiaimpact on resource use in in the Napu Valley, Central Sulawesi, Research project on stability rain forest margins (STORMA), University of Gottingen, Germany, No 13, January 2004.

[12] Elmhirst R., "Space, identity politics and resource control in Indonesia's transmigration programme", Elsevier Science Ltd, Political Geogpraphy, pp.813-835, Brighton, UK, 1999.

[13] Martanto U, "Ruang dan konflik wilayah : cerita dari enam desa", CSPS Monograph on Social Cohesion in North Maluku. Pusat Studi Keamanan dan Perdamaian, UGM, Yogyakarta, 2012.

[14] Sjaf Sofyan, "Politik Etnik - Dinamika politik lokal di Kendari." Yayasan Pustaka Obor Indonesia, Jakarta, 2014.

[15] Anthias. F, "Evaluating 'diaspora': beyond ethnicity", British Sociological Association Publication Ltd, Vol.32 no.3 pp. $557-$ 581. August 1998.

[16] Cohen. B, "Global diaspora: an introduction", Routledge Taylor and Francis group, London, pp. 163-168, 2008.

[17] Van Hear. N, Pieke. F and Vertovec.S, "The contribution of UKbased diasporas to development and poverty-reduction". Report of the ESRC Centre on Migration, Policy and Society, University of Oxford, p. 25, April 2004.

[18] Fukuyama.F, "Identity and migration", Prospect Magazine, issue 131, February 2007. 